\title{
Students' Perceived Quality of Library Facilities and Services in Nigerian Private Universities
}

\author{
Oluwunmi A. O. ${ }^{1}$, Durodola O. D. ${ }^{1}$, Ajayi C. A. ${ }^{2}$ \\ ${ }^{1}$ Department of Estate Management, Covenant University, Ota, Ogun State, Nigerian \\ ${ }^{2}$ Department of Estate Management, Obafemi Awolowo University, Ile Ife, Osun State, Nigerian \\ Correspondence: Oluwunmi, A. O., Department of Estate Management, Covenant University, Ota, Ogun State, Nigerian
}

Received: January 16, 2016 Accepted: January 28, 2016 Online Published: February 21, 2016

doi:10.11114/jets.v4i5.1396 URL: http://dx.doi.org/10.11114/jets.v4i5.1396

\begin{abstract}
In a highly competitive academic environment, students are becoming more selective and demanding in their choice of University. Hence, it is essential for educational institutions, particularly privately-owned institutions, to be interested in getting feedback on the quality of their facilities and services. With a focus on four private universities in Ogun State, Nigeria, this study examined students' perception of the quality of their library facilities and services. Using a modified SERVPERF questionnaire, seven hundred and forty-four (744) students were randomly selected and five hundred and eighteen (518) questionnaires were returned and analysed with SERVPERF dimensions (tangibility, responsiveness, reliability. assurance and empathy). Findings revealed that students' general perception of library services in the four (4) universities is above average, however, their perception of some facilities in the library like parking space and escape routes is very low. It is recommended that facility providers should ensure that university libraries facilities/services are given greater attention in budgeting, actual provision and quality improvement.
\end{abstract}

Keywords: students, library, Private Universities, educational institutions, Nigeria

\section{Introduction}

There is a need for service providers to consistently measure the performance of educational facilities' service quality particularly library services - for continuous improvement from the students' perspective. This is because students are directly involved in the education process hence it is essential to sample their views on the quality of services as well as the quality of education. The outcome of such research is expected to help the service provider to make judgements about the level of the quality of facilities provided in the educational institutions (Hill, Lomas and MacGregor, 2003; Jusoh, Omain, Majid, Md Som and Shamsuddin, 2004).

One of such facilities in educational institutions that students' opinion should be sought for maintaining academic excellence is the library. An effective and efficient academic library system is expected to contribute significantly to students' development (Ababio, Aidoo, Korankye, Saeed, Louis and Nsowah-Nuamah, 2012). According to Nwalo (2003), a library is effective when it is able to meet its users' needs relative to its goals and objectives. A library form part of the main components of every institution and hence, if under-resourced, it will undermine the very purposes of the institution (Khan and Zaidi, 2011).

In higher educational settings, several instruments for measuring service quality have been developed and formalised by authors such as SERVQUAL (Parasuraman et al., 1985, 1988; Zeithaml et al., 1990), SERVPERF (Carrilat, Jaramila and Mulki, 2007; Abdullah, 2005; Awan et al., 2008), SERVIMPERF (Anvari Rostami et al., 2005) and HEDPERF (Firdaus, 2005, 2006). The majority of research work in and outside Nigeria on the quality of library services have adopted the SERVQUAL instrument (Manjunatha and Shivalingaiah, 2004; Filiz, 2007; Khodayari and Khodayari, 2011; Ong and Nankervis, 2012; Asogwa, Asadu, Ezema, Ugwu and Ugwuanyi, 2014). However, this study used the SERVPERF instrument to measure students' perception of the quality of library facilities and services in four private Universities in Ogun State Nigeria. This method was chosen because the SERVPERF instrument is simpler, easier to use and its results are easier to analyse; thereby improving the chances of a higher response rate (Palmer, 2008; Wilson, Zeithaml, Bitner and Gremler, 2008). 


\section{Literature Review}

Interest in service quality in educational institutions has been on the increase globally and is receiving much attention in educational research. This may have been necessitated by the fact that higher education is facing commercial competition imposed by economic forces resulting from the development of global education markets and the reduction of government funding, forcing colleges and universities to seek other sources of financing (Coates, 2005; Lopez, 2005; Arpin, 2007; Munteanu, Ceobanu, Bobâlca and Anton, 2010).

The study of Tella, Owolabi and Attama (2009) examined the use of the library by students at the Akanu Ibiam Federal Polytechnic in Nigeria. Using a combined quantitative (questionnaires administered on students) and qualitative (in-depth interview with staff) approach, the study sampled students and staff of the polytechnic. One thousand (1000) questionnaires were distributed altogether to 200 students each from the five faculties of the polytechnic, and administration of interviews to 15 staff together with those who work in the school library. The findings showed that students were satisfied with the library collections and services. However, their satisfaction would have been enhanced if the school library had been networked with internet.

In Malaysia, Kassim (2009) evaluated the library's performance by measuring the users' satisfaction with (a) library services, (b) infrastructure/place/space and (c) collection/information provided by an academic library. The study sampled 650 final year students from three faculties in a public university in Malaysia to gauge their opinions on their satisfaction level on the statements regarding the three dimensions. Descriptive and inferential statistics were used to analyse the data using the Statistical Product and Service Solutions while a parametric test using the one-way analysis of variance (ANOVA) was used to compare the mean satisfaction scores among the respondents from the three faculties. The results of the study revealed that on the average, the respondents were satisfied with the library services, infrastructure/place/space, collection/information of the library as a whole. The respondents were relatively mostly satisfied with infrastructure/place/space $(\mathrm{M}=3.41)$, followed by collection/information $(\mathrm{M}=3.27)$, and library services to users $(M=3.18)$ in that order. The results also showed significant differences on the satisfaction on services, infrastructure/place/space, and libraries' collection/information among the respondents of the three faculties.

Kannappanavar and Swamy (2010) evaluated users' perception of the library and information services in agricultural university libraries in South India. The study administered questionnaires to three categories of users consisting: post-graduate students, research scholars and faculty members in five (5) agricultural university libraries. Out of 1,000 respondents, 765 questionnaires were returned and analysed. The analysis showed that users were satisfied with the information and services of the library; however, faculty members were more satisfied than other categories sampled.

The study conducted by Rehman, Shafique and Mahmood (2011) on user perception and satisfaction with reference services in university libraries of Punjab gathered a broad understanding of how users perceive the reference services they receive at Public Sector General University Libraries of the Punjab Province (Pakistan) and their satisfaction with these services. Out of 1,000 questionnaires administered, 507 were returned and analysed. The result of the study showed that respondents were satisfied with the reference collection, staff, facilities and services provided but they were not highly satisfied with any category of reference service.

Adeniran (2011) examined the relationship between service quality and users' satisfaction at Redeemer's University, Mowe, Nigeria. The study was set to find out if users of Redeemer's University library were satisfied with the services it renders. Questionnaires were administered to seven (7) academic staff and one hundred and seventy nine (179) students who visited and used the library within the period of research with the assistance of the library assistants. The result revealed that, of the academic staff and students who formed the population for the study, students were found to have used the library most and that users were satisfied with the services of the library.

Kannappanavar and Swamy (2012) evaluated users' perception and opinion on Users' Education Programmes in Agricultural University Libraries in India with special reference to South India. Out of 1000 respondents comprising of three categories of users, i.e. post-graduate students, research scholars and faculty members (at different levels), 765 (77\%) questionnaires were filled and analysed using descriptive and inferential statistics. The study showed that the majority of the post-graduate students $(284$, or $63.96 \%)$, research scholars $(88$, or $54.66 \%)$ and faculty members $(112$, or $70.00 \%)$ reported that they are satisfied with the user education programme conducted by the library personnel, eleven percent $(11 \%)$ of the users are partially satisfied and very few users reported that they are not satisfied with the user education programme.

A study by Abbasi, Malik, Chaudhry and Imdadullah (2011) measured the level of student satisfaction with services offered by Bahauddin Zakariya University (BZU), Pakistan. A general survey was conducted by means of a well structured questionnaire; through convenience sampling, it was administered to 401 students and data were collected from eighteen different disciplines and/or programs. Ten major constructs i.e. teaching, administrative/management support, transportation, library, computer labs and general labs, accommodation, medical, sports, prayer/religious 
facilities, and classroom facilities were used. Mean analysis reflected students dissatisfaction with many core services and facilities like teaching, administrative support, library, labs, accommodation, medical, and sports, while satisfaction was reported only in three augmented areas i.e. transportation, classroom and prayer facilities. Quite interestingly, no significant differences of opinion was recorded among male or female respondents. Overall, satisfaction level was alarmingly low and results indicated dissatisfaction of University students with educational services offered by Pakistani universities.

Iwhiwhu and Okorodudu (2012) carried out a study on users' satisfaction with library information resources, facilities and services in Edo State Central Library, Benin-City, Nigeria. Two hundred (200) respondents were selected using the availability sampling technique. Questionnaire and observation were the instruments used for data collection and the data was analyzed using descriptive statistics such as percentages, frequencies and mean. The result revealed that users were not satisfied with the information resources and they were only satisfied with three services provided in the library, which are hours of service, labelling services and bindery services with a mean of 2.87, 2.32 and 2.88 respectively. However, they were satisfied with the furniture available.

A few studies also exist that adopted SERVPERF to measure the quality of library services. The study of Bigne, Moliner and Sanchez (2003) in Spain evaluated the relationships between perceived quality and satisfaction in two publicly-owned multi-service organisations: hospitals and universities. According to the authors, these organisations offer a range of services to their customers. The study distributed SERVPERF questionnaires to 275 respondents of six public hospitals and 333 students of the Business Administration diploma and degree programmes at two universities in Spain. The results at the public Universities showed that the perception of the core service quality (teaching quality) was dominant for overall quality but that does not indicate that the peripheral services quality (library quality, information attention quality, and registration quality) should be neglected by the universities.

In Malaysia, Johari and Zainab (2007) described an exploratory case study which used a modified version of SERVPERF to assess users' satisfaction with the services provided at a private university's library. A total of 59 service attributes were grouped as frontline, core and peripheral; these attributes were extracted and used to measure staff and facilities' opinions and expectations. The study sampled 274 students, comprising 250 undergraduate and 24 postgraduate who were randomly chosen for two days as they visited the library. Out of 22 frontline services which focused on the OPAC services, the library website and user education programmes, 3 services were rated as good, 3 as poor and the rest as average. Out of 29 core service statements which focused on the adequacy of library materials, equipment and staff in supporting learning, 13 were rated as good, 2 as poor and the rest received average ratings. The library performed better on the peripheral services, which focused on the physical environment and facilities where 2 out of 8 service statements were rated as excellent, 4 as good and the rest as average. The overall service quality was rated between 3.13 and 4.36 on a 5-point scale, which implied an average performance level.

Another study by Nadiri, Kandampully and Hussain (2009) measured students' perceptions of higher education service quality via a SERVPERF model in Turkey. The study conducted a pilot study of 50 students using SERVPERF dimensions to cover perceived service quality of university administrative units (e.g. services by the registrar, library, faculty/school offices, rector office, dormitories, sports and health centre). A five-point Likert-style questionnaire covering tangibles (four items), intangibles (18 items) and satisfaction (two items) was distributed to students at Famagusta's Eastern Mediterranean University (North Cyprus) in 2007 and the result analysed using descriptive and inferential statistics. Findings showed that SERVPERF can provide diagnostics for management action as the tangible and intangible items proved good satisfaction predictors through explaining $64 \%$ of variance in student satisfaction.

From the above reviews, little or no research has been conducted in Nigerian university library to investigate students' perception of quality of facilities and service using SERVPERF. It is on this note that this study is set to examine students' view of the quality of library facilities and services in four private universities in Ogun State, Nigeria.

\subsection{Study Area}

The study focused on Ogun State which hosts sixteen (16) accredited tertiary institutions out of which eleven (11) are universities (i.e. $70 \%$ of the total number of tertiary institutions in Ogun State). Out of these, three (3) are government owned while the remaining eight (8) are privately owned. Four (4) out of these privately owned universities which started full operation in 2005 constitute the focus of this study. These universities are described in Table 1. 
Table 1. List of Selected Private Universities, Year Established and Ownership

\begin{tabular}{clcc}
\hline S/N & \multicolumn{1}{c}{ Name of Institution } & Year Established & Ownership \\
\hline 1 & Redeemers' University (RUN) & 2005 & Missionary \\
2 & Bells University (Bells) & 2005 & Non-missionary \\
3 & Crescent University (CRE) & 2005 & Missionary \\
4 & Crawford University (CRA) & 2005 & Missionary \\
\hline
\end{tabular}

\section{Research Methods}

The statistical formula by Asika (2004) was used to determine appropriate sample size for this study. The formula is as follows:

$$
\mathrm{n}=\mathrm{N} / 1+\mathrm{N}(\mathrm{b})^{2}
$$

Where:

$$
\begin{aligned}
& \mathrm{n}=\text { required sample size } \\
& \mathrm{N}=\text { Population Size } \\
& \mathrm{b}=\text { Maximum acceptable error margin }(10 \%)
\end{aligned}
$$

Using the formula, a total of 744 modified SERVPERF questionnaires were randomly administered to students (see Table 2). The original SERVPERF scale contains 22 statements; however, the modified SERVPERF used for this study contains 31 statements (see Appendix A) categorised under Tangibility (statements 1 - 15); Responsiveness (statements 16 - 18); Reliability (statements 19 - 22); Assurance (statements 23 - 26) and Empathy (statements 27 - 31)]. Students' opinions were measured using a 5-point Likert scale and data were analysed using descriptive statistical techniques. The original SERVPERF was modified to accommodate more facilities under the tangibility dimension which was essential for the objective of this study to be achieved. For example, the original SERVPERF statement did not make provision for facilities like toilets, escape routes and library space per student, amongst others.

\section{Results}

Out of the 744 SERVPERF questionnaires administered to students in the selected private universities, a response rate of $70 \%$ was achieved. (see Table 2). $44 \%$ of the students were male while the remaining $56 \%$ were female; majority of the

\begin{tabular}{|c|c|c|c|c|}
\hline \multirow[b]{2}{*}{$\mathbf{S} / \mathbf{N}$} & \multirow[b]{2}{*}{ University } & \multicolumn{2}{|c|}{ No. of Questionnaires } & \multirow[b]{2}{*}{ Percentage $(\%)$} \\
\hline & & Administered & Retrieved & \\
\hline 1 & Redeemers' University (RUN) & 187 & 140 & 75 \\
\hline 2 & Bells University (Bells) & 187 & 116 & 62 \\
\hline 3 & Crescent University (CRE) & 186 & 108 & 58 \\
\hline \multirow[t]{2}{*}{4} & Crawford University (CRA) & 184 & 154 & 84 \\
\hline & Total & 744 & 518 & 70 \\
\hline
\end{tabular}
students were Science and Technology-based (59\%), single (99\%) and sponsored by their parents (86\%). They were between 16 and 25 years (93\%), in 200 and 300-level (60\%) of their programmes (see Table 3).

Table 2. Response Rate 
Table 3. Comparison of Students' Characteristics across the Four Private Universities

\begin{tabular}{|c|c|c|c|c|c|c|c|}
\hline \multirow[t]{2}{*}{$\mathbf{S} / \mathbf{N}$} & \multirow{2}{*}{$\begin{array}{c}\text { Characteristics } \\
\text { /Statistics }\end{array}$} & \multirow{2}{*}{$\begin{array}{c}\text { Sub- } \\
\text { headings }\end{array}$} & \multirow{2}{*}{$\begin{array}{c}\text { RUN } \\
\text { F (\%) }\end{array}$} & \multirow{2}{*}{$\begin{array}{c}\text { Bells } \\
\text { F (\%) }\end{array}$} & \multirow{2}{*}{$\begin{array}{c}\text { CRE } \\
\text { F (\%) }\end{array}$} & \multirow{2}{*}{$\begin{array}{c}\text { CRA } \\
\text { F (\%) }\end{array}$} & \multirow{2}{*}{$\begin{array}{c}\text { Mean } \\
\%\end{array}$} \\
\hline & & & & & & & \\
\hline \multirow[t]{3}{*}{1} & Academic & Science \& Technology & $37(26)$ & $86(74)$ & $62(57)$ & $118(77)$ & 59 \\
\hline & Programme & Social Science & $85(61)$ & $30(26)$ & $28(26)$ & $36(23)$ & 34 \\
\hline & Classification & Humanities & $18(13)$ & N/A & $18(17)$ & N/A & 7 \\
\hline \multirow[t]{7}{*}{2} & Sex & Male & $50(36)$ & $60(52)$ & $56(52)$ & $59(38)$ & 44 \\
\hline & & Female & $90(64)$ & $56(48)$ & $52(48)$ & $92(62)$ & 56 \\
\hline & Age & $<16$ yrs & $1(1)$ & $0(0)$ & $10(9)$ & $6(4)$ & 3 \\
\hline & & $16-20 \mathrm{yrs}$ & $115(82)$ & $53(46)$ & $49(45)$ & $112(73)$ & 62 \\
\hline & & $21-25$ yrs & $24(17)$ & $59(51)$ & $41(38)$ & $30(19)$ & 31 \\
\hline & & $26-30 \mathrm{yrs}$ & $0(0)$ & $4(3)$ & $6(6)$ & $6(4)$ & 3 \\
\hline & & $>30 \mathrm{yrs}$ & $0(0)$ & $0(0)$ & $2(2)$ & $0(0)$ & 1 \\
\hline \multirow[t]{5}{*}{4} & Year of Study & 100-Level & $68(48)$ & $9(8)$ & $11(10)$ & $0(0)$ & 17 \\
\hline & & 200-Level & $29(21)$ & $14(12)$ & $51(47)$ & $74(48)$ & 32 \\
\hline & & 300-Level & $38(27)$ & $61(52)$ & $19(18)$ & $61(40)$ & 34 \\
\hline & & 400-Level & $5(4)$ & $23(20)$ & $23(21)$ & $19(12)$ & 14 \\
\hline & & 500-Level & $0(0)$ & $9(8)$ & $4(4)$ & $0(0)$ & 3 \\
\hline \multirow[t]{3}{*}{5} & Type of & Self & $0(0)$ & $0(0)$ & $8(7)$ & $0(0)$ & 2 \\
\hline & Sponsorship & Parent & $133(95)$ & $96(83)$ & $96(89)$ & $121(79)$ & 86 \\
\hline & & Guardian & $7(5)$ & $20(17)$ & $4(4)$ & $33(21)$ & 12 \\
\hline \multirow[t]{2}{*}{6} & Marital Status & Single & $140(100)$ & $116(100)$ & $102(94)$ & $154(100)$ & 99 \\
\hline & & Married & $0(0)$ & $0(0)$ & $6(6)$ & $0(0)$ & 1 \\
\hline
\end{tabular}

4.1 Students' Perception of the Quality of Library Facilities and Service in Four Private Universities

This section analyses questions that bordered on knowing students' perception of the quality of service in their University library. Tables 4 gives a summary of the analysis of the responses from the four (4) private Universities. Responses were in terms of "Strongly Agree", "Agree", "Uncertain", "Disagree" and "Strongly Disagree" were assigned scores of 5, 4, 3, 2 and 1 respectively and the mean calculated. 
Table 4. Students' Perception of Library Facilities and Services: Comparison of Mean Scores across Four Private Universities

\begin{tabular}{|c|c|c|c|c|c|c|}
\hline \multirow{2}{*}{$\begin{array}{l}\text { Service Quality } \\
\text { Dimensions }\end{array}$} & \multirow[t]{2}{*}{ Services } & RUN & Bells & CRE & CRA & \multirow{2}{*}{$\begin{array}{c}\text { Average } \\
\text { Mean }\end{array}$} \\
\hline & & Mean & Mean & Mean & Mean & \\
\hline \multirow{15}{*}{ Tangibility } & $\mathrm{S} 1$ & 4.14 & 3.06 & 4.10 & 3.05 & 3.59 \\
\hline & $\mathrm{S} 2$ & 4.16 & 3.78 & 4.25 & 2.99 & 3.80 \\
\hline & $\mathrm{S} 3$ & 4.41 & 3.72 & 3.93 & 3.29 & 3.84 \\
\hline & $\mathrm{S} 4$ & 4.41 & 3.72 & 3.39 & 3.47 & 3.75 \\
\hline & S5 & 4.39 & 3.78 & 3.38 & 3.49 & 3.76 \\
\hline & S6 & 4.28 & 3.66 & 3.65 & 3.37 & 3.74 \\
\hline & S7 & 4.27 & 3.72 & 3.77 & 3.35 & 3.78 \\
\hline & S8 & 1.86 & 2.20 & 3.84 & 2.48 & 2.60 \\
\hline & S9 & 4.14 & 4.11 & 3.77 & 3.44 & 3.87 \\
\hline & S10 & 4.16 & 3.48 & 3.01 & 3.27 & 3.48 \\
\hline & S11 & 4.09 & 3.47 & 2.85 & 3.19 & 3.40 \\
\hline & S12 & 4.19 & 3.52 & 3.10 & 3.18 & 3.50 \\
\hline & S13 & 1.59 & 2.06 & 3.01 & 3.12 & 2.45 \\
\hline & S14 & 4.29 & 4.28 & 4.41 & 3.58 & 4.14 \\
\hline & S15 & 3.06 & 3.53 & 3.68 & 3.53 & 3.45 \\
\hline Average Tangibility & & 3.83 & 3.47 & 3.61 & 3.25 & 3.54 \\
\hline \multirow{3}{*}{ Responsiveness } & S16 & 4.28 & 3.60 & 3.67 & 3.34 & 3.72 \\
\hline & S17 & 4.40 & 3.63 & 3.57 & 2.94 & 3.64 \\
\hline & S18 & 4.34 & 3.46 & 3.63 & 3.05 & 3.62 \\
\hline Average Responsiveness & & 4.34 & 3.56 & 3.62 & 3.11 & 3.66 \\
\hline \multirow{4}{*}{ Reliability } & S19 & 4.37 & 3.28 & 3.72 & 3.12 & 3.63 \\
\hline & S20 & 4.26 & 3.62 & 3.43 & 3.14 & 3.61 \\
\hline & $\mathrm{S} 21$ & 4.34 & 3.76 & 3.21 & 3.08 & 3.60 \\
\hline & S22 & 4.29 & 3.62 & 3.28 & 3.08 & 3.57 \\
\hline \multirow[t]{2}{*}{ Average Reliability } & & 4.32 & 3.57 & 3.41 & 3.11 & 3.60 \\
\hline & $\mathrm{S} 23$ & 4.39 & 3.64 & 3.54 & 3.04 & 3.65 \\
\hline \multirow{3}{*}{ Assurance } & $\mathrm{S} 24$ & 4.34 & 3.79 & 3.10 & 3.07 & 3.58 \\
\hline & $\mathrm{S} 25$ & 4.32 & 3.61 & 3.49 & 3.00 & 3.60 \\
\hline & S26 & 4.26 & 3.73 & 3.02 & 3.14 & 3.54 \\
\hline \multirow[t]{2}{*}{ Average Assurance } & & 4.33 & 3.69 & 3.29 & 3.06 & 3.60 \\
\hline & S27 & 4.24 & 3.71 & 3.30 & 3.08 & 3.58 \\
\hline \multirow{4}{*}{ Empathy } & $\mathrm{S} 28$ & 4.28 & 3.69 & 3.73 & 3.27 & 3.74 \\
\hline & S29 & 4.43 & 3.72 & 3.73 & 3.28 & 3.79 \\
\hline & $\mathrm{S} 30$ & 4.39 & 3.79 & 3.49 & 3.22 & 3.72 \\
\hline & $\mathrm{S} 31$ & 4.33 & 3.22 & 3.35 & 3.16 & 3.52 \\
\hline Average Empathy & & 4.33 & 3.63 & 3.52 & 3.20 & 3.67 \\
\hline \multicolumn{7}{|c|}{ Overall Average $=3.61$} \\
\hline
\end{tabular}

An Examination of Table 4 reveals that the average service quality dimension of the respondents on tangibility, responsiveness, reliability, assurance and empathy are 3.54,3.66, 3.60, 3.60 and 3.67 respectively. However, empathy has the highest mean score while tangibility has the least mean score. Generally, across the five service quality dimensions, 
students indicated that there is inadequate parking space (2.60) and escape routes (2.45) in their university libraries. In addition to these, their ranking also revealed that they are fairly satisfied with space per student, the number of toilets and water supply. However, RUN students are satisfied with the number of toilets in their university library while they are indifferent about the reading space per student. In general, the overall average service quality dimension across the four universities is 3.61. This means that the library score was above average in all the five dimensions as well as on an overall basis. This indicates that students' perception of library services in the four (4) universities is above average. But on individual universities basis, RUN had the highest score for average tangibility (3.84), responsiveness (4.34), reliability (4.32), assurance (4.33) and empathy (4.33) while CRA had the lowest in the five dimensions (tangibility = 3.25 ; responsiveness $=3.11$; reliability $=3.11$, assurance $=3.06$ and empathy $=3.20$ ).

A closer look at the analysis based on the five dimensions per university reveals that RUN students chose responsiveness as the service they enjoy the most and tangibility as the service which gives them the least satisfaction. At the Bells, assurance was their best and tangibility the least. In CRE, responsiveness was the best and assurance the least; and for CRA, tangibility was the best and assurance was the least. The implications of these findings is that the students in RUN and Bells perceive the physical facilities and appearance of personnel in the library as not satisfactory enough while students in CRE and CRA perceive their library staff as unfriendly and discourteous and they do not demonstrate adequate knowledge of their work.

The data further showed that RUN and CRE have sufficient relevant books and journals in their libraries with databases in good working condition when compared to Bells' and CRA's libraries. With respect to furniture and equipment in the library of the universities sampled, RUN and Bells students were more satisfied than CRE and CRA students. It was also noted that CRA students perceive that their library study room is not comfortable, electricity in the library is not constant and the general reading environment is noisy. The implication of this is that the students in this university might find it difficult to cultivate the habit of reading in their university library.

\section{Recommendations and Conclusion}

It was established from this study that as far as building elements and installations are concerned, the needs of the students when checked across the selected universities were not met with respect to the number of escape routes, parking space, space available per student, number of toilets and water supply in their library. Hence, it is suggested that the facility providers should take note of these needs so as to be able to respond appropriately. This will entail ensuring that areas with a low level of students' satisfaction in the University libraries are given greater attention in budgeting, actual provision and quality improvement. This is because there is no gainsaying the fact that a satisfied student will be a strong motivator of others to prefer the university whose facilities he/she finds so satisfying. By implication, this means greater patronage for that university. 


\section{Reference}

Ababio, A. K., Aidoo, E. N., Korankye, T., Saeed, B. I. I, Munyakasi, L., \& Nsowah-Nuamah, N. N. N. (2012). Modelling Student's Satisfaction with Library Services in Tertiary Institutions: Evidence from Kumasi Polytechnic, Information and Knowledge Management Journal, 2(6), 85-94.

Abbasi, M. N., Malik, A., Chaudhry, I. S., \& Imdadullah, M. (2011). A Study on Student Satisfaction in Pakistani Universities: The Case of Bahauddin Zakariya University, Pakistan. Asian Social Science, 7, $209-219$. http://dx.doi.org/10.5539/ass.v7n7p209

Abdullah, F. (2005). HedPERF vs. SERVPERF: The Quest for Ideal Measuring Instrument of Service Quality in Higher Education Sector. Quality Assurance Education, 13(4), 305-328. http://dx.doi.org/10.1108/09684880510626584

Adeniran, P. (2011). User Satisfaction with Academic Libraries Services: Academic Staff and Students Perspectives, International Journal of Library and Information Science, 3, 209-216.

Anvari, R. E.A., Torabi, G. M., \& Mohammadloo, A. (2005). Comparison of Banking Services Quality from Viewpoints of Customers and Staff. Modarres Human Sciences, 4(3), 23-34.

Arpin, J. (2007). Students’ Perceptions of Service Quality at the Durban University of Technology, (Unpublished Master's Thesis), Business Studies Unit, DurbanUniversity of Technology Faculty of Commerce. Durban

Asogwa, B. E., Asadu, B. U., Ezema, J. U., Ugwu, C. I., \& Ugwuanyi, F. C. (2014). Use of ServQUAL in the Evaluation of Service Quality of Academic Libraries in Developing Countries, Library Philosophy and Practice (e-journal). http://digitalcommons.unl.edu/cgi/viewcontent.cgi?article=2947\&context=li bphilprac

Awan, M. U, Azam, S., \& Asif, M. (2008). Library Service Quality Assessment. Journal of Quality Technology Management, 4(1), 51-64.

Bigne, E., Moliner, M. A., \& Sanchez, J. (2003). Perceived Quality and Satisfaction in Multi-service Organizations: The Case of Spanish Public Services. The Journal of Services Marketing, 17(4), 420-442. http://dx.doi.org/10.1108/08876040310482801.

Carillat, A. F, Jaramila, F., \& Mulki, P. J. (2007). The Validity of the SERVQUAL and Meta-analytic View of 17-years of Research across 5 Continents. Journal

SERVPERF Scales: A Management, 18(5), 472-490. http://dx.doi.org/10.1108/09564230710826250.

Coates, H. (2005). The Value of Student Engagement for Higher Education Quality Assurance. Quality in Higher Education, 11(1), 25-36.

Filiz, Z. (2007). Service Quality of University Library: A Survey amongst Students at Osmangazi University and Anadolu University. Ekonometri Ve Istatistik Sayi, 5, 1-19.

Firdaus, A. (2005). The Development of HEdPERF: A New Measuring Instrument of Service Quality for Higher Education. International Journal of Consumer Studies, online publication, 20 October.

Firdaus, A. (2006). The Development of HEdPERF: A New Measuring Instrument of Service Quality for the Higher Education Sector. International Journal of Consumer Studies, 30(6), 569-581. http://dx.doi.org/10.1111/j.1470-6431.2005.00480.

Hill, Y., Lomas, L., \& MacGregor, J. (2003). Students' Perceptions of Quality in Higher Education, Quality Assurance in Education, 11(1), 15-20. http://dx.doi.org/10.1108/09684880310462047

Iwhiwhu, B. E., \& Okorodudu, P. O. (2012). Public Library Information Resources, Facilities and Services: Users Satisfaction with Edo State Central Library, Benin City, Nigeria. Library Philosophy and Practice (e-journal). http://digitalcommons.unl.edu/libphilprac/747/

Johari, R., \& Zainab, A. N. (2007). Identifying What Services Need To Be Improved by Measuring the Library's Performance. Malaysian Journal of Library and Information Science, 12(1), 35-53.

Jusoh, A., Omain, S. Z., Majid, N. A., Md Som, H., \& Shamsuddin, A. S. (2004). Service Quality in Higher Education: Management Students' Perspective. A Research Submitted to Management Department, Faculty of Management and Human Resource Development, University of Technology, Malaysia.

Kannappanavar, B. U., \& Swamy, H. M. C. (2010). User Perception of Library and Information Services in Agricultural Science Universities in South India: An Evaluative Study, Library Philosophy and Practice. (e-journal). http://digitalcommons.unl.edu/cgi/viewcontent.cgi?article=1365\&context=libphilprac

Kannappanavar, B. U., \& Swamy, H. M. C. (2012). User Education in Agricultural Science University Libraries in 
India with Special reference to South India. Library Philosophy and Practice (e-journal). http://digitalcommons.unl.edu/libphilprac/720

Kassim, N. A. (2009). Evaluating Users' Satisfaction on Academic Library Performance. Malaysian Journal of Library \& Information Science, 14(2), 101-115.

Khan, A. M., \& Zaidi, S. M. (2011). Determinants of Library's Effectiveness and Ffficiency: A Study of Collection Development, Organization and Services of Maulana Azad Library, AMU (India). Library Collections, Acquisitions, \& Technical Services, 35(4), 95-105. http://dx.doi.org/10.1016/j.lcats.2011.08.002

Khodayari, F., \& Khodayari, B. (2011). Service Quality in Higher Education, Case Study: Measuring Service Quality of Islamic Azad University; Firoozkooh Branch. Interdisciplinary Journal of research in Business, 1(9), 38-46.

Lopez, I. (2005). Building Universities of Quality: An Analysis of the Views of University Students Concerning their Academic Training, Higher Education in Europe, 30(3), 321-334. http://dx.doi.org/10.1080/03797720600625275a

Manjunatha, K., \& Shivalingaiah, D. (2004). Customer's Perception of Service Quality in Libraries. Annals of Library and Information Studies, 51(4), 145-151.

Munteanu, C., Ceobanu, C., Bobâlca, C., \& Anton, O. (2010). An Analysis of Customer Satisfaction in a Higher Education Context. International Journal of Public $\quad$ Sector $\quad$ Management, $\quad 23(2), \quad$ 124-140. http://dx.doi.org/10.1108/09513551011022483

Nadiri, H., Kandampully, J., \& Hussain, K. (2009). Students' Perceptions of Service Quality in Higher Education. Total Quality Management and Business Excellence, 20(5), 523-535.

Nwalo, K. I. N. (2003). Fundamentals of Library Practice: A Manual on Library Routines. Ibadan: Stirling Horden Publishers

Ong, W. M., \& Nankervis, A. (2012). Service Quality in Higher Education: Students' Perceptions in Australia and Malaysia. Review of Integrative Business and Economic Research, 1(1), 277-290.

Palmer, A. (2008). Principles of Service Marketing. 5th Edition London: The McGraw-Hill Companies.

Parasuraman, A., Zeithaml, V. A., \& Berry, L. L. (1985). A Conceptual Model of Service Quality and its Implication. Journal of Marketing, 49, 41-50. http://dx.doi.org/10.2307/1251430

Parasuraman, A., Zeithaml, V. A., \& Berry, L. L. (1988). SERVQUAL: A Multi-Item Scale for Measuring Consumer Perceptions of the Service Quality. Journal of Retailing, 64, 12-40.

Tella, A., Owolabi, K. A., \& Attama, R. O. (2009). Student Use of the Library: A Case Study at Akanu Ibiam Federal Polytechnic, Unwana, Nigeria, Chinese Librarianship: An International Electronic Journal, 28. http://www.iclc.us/cliej/cl28TOA.htm

Wilson, A., Zeithaml, V., Binter, M., \& Gremler, D. (2008). Service Marketing: Integrating Customer Focus Across the Firm . London: The McGraw-Hill Companies.

Zeithaml V.A., Parasuraman A., \& Berry L.L. (1990). Delivering Quality Service: Balancing Customer Perceptions and Expectations. The Free Press, New York. NY. 


\section{Appendix}

Modified SERVPERF Questions for Library Facilities and Services

\begin{tabular}{|c|c|c|c|}
\hline $\mathbf{S} / \mathbf{N}$ & Dimension of Service Quality Attribute & $\mathbf{S} / \mathbf{N}$ & Dimension of Service Quality Attribute \\
\hline 1 & $\begin{array}{l}\text { There is a sufficient number of relevant books and } \\
\text { journals in the library }\end{array}$ & 17 & $\begin{array}{l}\text { Library staff are well-trained and answer all the } \\
\text { queries of the users }\end{array}$ \\
\hline 2 & $\begin{array}{l}\text { Database in the library is in good working order } \\
\text { and condition }\end{array}$ & 18 & Staff are ready to respond to user requests \\
\hline 3 & The study area is comfortable & 19 & $\begin{array}{l}\text { The library collections are current and shelved } \\
\text { accurately }\end{array}$ \\
\hline 4 & $\begin{array}{l}\text { There is a sufficient number of study rooms, } \\
\text { conferences and computers }\end{array}$ & 20 & The loan and return records are accurate \\
\hline 5 & There is sufficient natural and artificial lighting & 21 & $\begin{array}{l}\text { The content of library website is abundant and } \\
\text { sufficient }\end{array}$ \\
\hline 6 & The overall reading environment is quiet & 22 & Library staff are able to answer questions accurately \\
\hline 7 & The environment is well maintained & 23 & $\begin{array}{l}\text { Directional signs in the building are clear to } \\
\text { understand }\end{array}$ \\
\hline 8 & There is sufficient parking space around the library & 24 & Library staff are friendly and courteous \\
\hline 9 & $\begin{array}{l}\text { There is sufficient furniture (e.g. chairs, tables) and } \\
\text { equipment (e.g printers, computers) in the library }\end{array}$ & 25 & Library staff are aware of every service item \\
\hline 10 & There are separate toilets for male and female & 26 & $\begin{array}{l}\text { Library staff demonstrate adequate knowledge of } \\
\text { their work and perform efficiently }\end{array}$ \\
\hline 11 & There is a sufficient number of toilets & 27 & $\begin{array}{l}\text { The library provides book loan and return service, } \\
\text { daily newspapers and training courses for users }\end{array}$ \\
\hline 12 & There is sufficient water supply in the toilets & 28 & $\begin{array}{l}\text { The book collections meet the needs of each of the } \\
\text { courses in the University }\end{array}$ \\
\hline 13 & There is an adequate number of escape routes & 29 & $\begin{array}{l}\text { The regular length of opening hours and loan } \\
\text { deadline are satisfactory }\end{array}$ \\
\hline 14 & There is adequate electricity supply & 30 & $\begin{array}{l}\text { The library provides electronic publications and } \\
\text { electronic database }\end{array}$ \\
\hline 15 & There is adequate space per student & 31 & $\begin{array}{l}\text { The library provide areas for data research on the } \\
\text { first floor }\end{array}$ \\
\hline 16 & Library staff are competent & & \\
\hline
\end{tabular}

\section{$(c))$ EY}

This work is licensed under a Creative Commons Attribution 3.0 License. 